San Jose State University

SJSU ScholarWorks

Master's Theses

Master's Theses and Graduate Research

1994

\title{
The effects of the Rood Cone on hand function in children with spastic cerebral palsy
}

Emily M. Devere

San Jose State University

Follow this and additional works at: https://scholarworks.sjsu.edu/etd_theses

\section{Recommended Citation}

Devere, Emily M., "The effects of the Rood Cone on hand function in children with spastic cerebral palsy" (1994). Master's Theses. 902.

DOI: https://doi.org/10.31979/etd.fc35-yx7c

https://scholarworks.sjsu.edu/etd_theses/902

This Thesis is brought to you for free and open access by the Master's Theses and Graduate Research at SJSU ScholarWorks. It has been accepted for inclusion in Master's Theses by an authorized administrator of SJSU ScholarWorks. For more information, please contact scholarworks@sjsu.edu. 


\section{INFORMATION TO USERS}

This manuscript has been reproduced from the microfilm master. UMI films the text directly from the original or copy submitted. Thus, some thesis and dissertation copies are in typewriter face, while others may be from any type of computer printer.

The quality of this reproduction is dependent upon the quality of the copy submitted. Broken or indistinet print, colored or poor quality illustrations and photographs, print bleedthrough, substandard margins, and improper alignment can adversely affect reproduction.

In the unlikely event that the author did not send UMI a complete manuscript and there are missing pages, these will be noted. Also, if unauthorized copyright material had to be removed, a note will indicate the deletion.

Oversize materials (e.g., maps, drawings, charts) are reproduced by sectioning the original, beginning at the upper left-hand corner and contimuing from left to right in equal sections with small overlaps. Each original is also photographed in one exposure and is included in reduced form at the back of the book.

Photographs included in the original manuscript have been reproduced xerographically in this copy. Higher quality $6^{\prime \prime} \times 9^{n}$ black and white photographic prints are available for any photographs or illustrations appearing in this copy for an additional charge. Contact UMI directly to order.

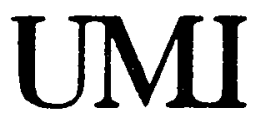

A Bell \& Howell information Company 300 North Zeeb Road. Ann Arbor. M1 48106-1346 USA 313:761-4700 800:521-0600 


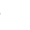




\title{
THE EFFECTS OF THE ROOD CONE ON HAND FLNCTION IN CHILDREN WITH SPASTIC CEREBRAL PALSY
}

\author{
A Thesis \\ Presented to \\ The Department of Occupational Therapy \\ San Jose State University \\ In Partial Fulfillment \\ of the Requirements for the Degree \\ Master of Science
}

by

Emily M. Devere

December, 1994 
UMI Number: 1361160

UMI Microform Edition 1361160

Copyright 1995, by UMI Company. All rights reserved.

This microform edition is protected against unauthorized copying under Title 17, United States Code.

\section{UMI}

300 North zeeb Road

Ann Arbor, MI 48103 
(c) 1994

Emily Marmara Devere

ALL RIGHTS RESERVED 
APPROVED FOR THE DEPARTMENT OF OCCUPATIONAL THERAPY Hosdín $\angle A$ Buster Gordon U. Burton, Ph.D., O.T.R.

sem 7 m cormack Guy McCormack, M.S., O.T.R.

House Anger LTR Louise Sumpter, O.T.R.

APPROVED FOR THE UNIVERSITY Serene Ir. Stanford 


\title{
ABSTRACT \\ THE EFFECTS OF THE ROOD CONE ON HAND FUNCTION IN CHILDREN WITH SPASTIC CEREBRAL PALSY
}

\author{
by Emily M. Devere
}

This study examined the effectiveness of the use of the Rood Cone in children who have hypertonia in their hand(s).

The subjects were students in the Special Education Department of the Fresno Unified School System. Initial measurements of active range of motion, passive range of motion and cube stacking were taken. The children were asked to position the Cone in the hand for three hours in the morning, and four hours in the afternoon for one month. At which time, a posttest was administered. The Cone was then removed, and after another month's time, the final posttest was administered.

The significant results were as follows: With the wearing of the Cone, active thumb abduction and metacarpal extension increased, and decreased after the removal of the Cone; passive thumb abduction also increased with the wearing of the Cone, and decreased after the removal of the Cone. 


\section{ACKNOWLEDGMENTS}

I would like to thank my thesis advisor, Dr. Gordon U. Burton, Ph.D., O.T.R., for making the process go so smoothly, and for his wise and candid input.

Fred Sammons was very generous in donating all the pediatricsized hand cones and measuring devices/equipment needed for this study, as well as financial support.

I would like to thank Dr. Ric Brown for directing me in my statistical analysis.

I would like to thank my husband, John, and my Mom and Dad, Martha and Robert Bair, who have been a great support to me during this learning process, and who have sustained my efforts in completing my thesis.

Encouragement to conduct this study came from both local therapists working with children through California Children Services, and from faculty of San Jose State University, Department of Occupational Therapy. Amongst those individuals is one whom I miss greatly, Janet Down, M.S., O.T.R. She has been a great influence on me in pursuing my career in pediatric Occupational Therapy, and was a kind, cheerful, energetic friend and professor.

A small grant award, received by the author for this study through San Jose State College of Applied Sciences and Arts, further facilitated completion of this research. 


\section{TABLE OF CONTENTS}

Chapter

Page

1. INTRODUCTION $\ldots \ldots \ldots \ldots \ldots \ldots \ldots \ldots \ldots \ldots$

Statement of the Problem .................

Significance of the Study $\ldots \ldots \ldots \ldots \ldots \ldots \ldots 2$

2. REVIEW OF THE LITERATURE $\ldots \ldots \ldots \ldots \ldots \ldots \ldots$

3. DESIGNAND METHODOLOGY $\ldots \ldots \ldots \ldots \ldots \ldots \ldots \ldots$

Research Purpose and Question .............11

Research Objective, Questions, Hypotheses ...... 11

Definitions ........................ 13

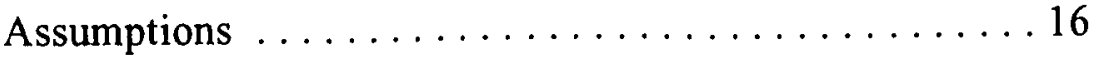

Limitations $\ldots \ldots \ldots \ldots \ldots \ldots \ldots \ldots \ldots \ldots \ldots$

Population $\ldots \ldots \ldots \ldots \ldots \ldots \ldots \ldots \ldots \ldots \ldots \ldots \ldots \ldots \ldots$

Methodology ........................ 18

Procedures $\ldots \ldots \ldots \ldots \ldots \ldots \ldots \ldots \ldots \ldots$ 
Measurements ......................21

Data Analysis .......................23

4. DATA ANALYSIS AND RESULTS $\ldots \ldots \ldots \ldots \ldots \ldots 24$

5. SUMMARY, FINDINGS, CONCLUSIONS, AND

RECOMMENDATIONS . ................. 31

Findings and Conclusions ................ 32

Discussion and Recommendations ............ 36

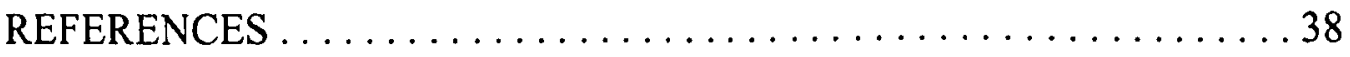

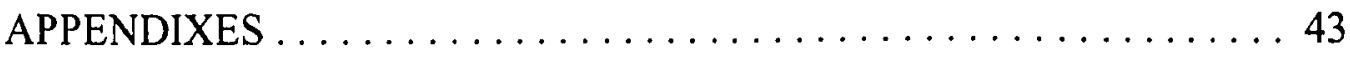

A. HUMAN SUBJECTS APPROVAL $\ldots \ldots \ldots \ldots \ldots \ldots 44$

B. LETTER OF CONFIRMATION-FRESNO UNIFIED ........46

C. LETTER OF CONFIRMATION-PRINCIPAL . ....... 48

D./E. REQUEST FOR PARTICIPATION-ENGLISH \& SPANISH .. 50

F./G. BRIEF NOTE TO PARENTS-ENGLISH \& SPANISH . . . . . 53

H./l. FORMATIVE AGREEMENT-ENGLISH \& SPANISH . . . . . . 56

J./K. CONSENT TO PHOTOGRAPH $\ldots \ldots \ldots \ldots \ldots \ldots \ldots, 61$ 


\section{Chapter 1}

\section{INTRODUCTION}

\section{Statement of the Problem}

Most reports on splinting and hand function in children with spastic cerebral palsy are descriptive in nature. They simply report on the theoretical rationale for the splint. Experimental research on the use of splinting for this population is minimal (Exner, 1983).

MacKinnon, Sanderson, and Buchanan (1975) and Farber (1973) documented the theoretical use of splints, emphasizing neurophysiologic approaches to treatment. Farber (1973) theorized and rationalized the use of a hard cone in the palm of the hand to facilitate extension and inhibit flexion. No documentation of use of this splint with individuals exhibiting spasticity is provided. A more recent study relied upon the biomechanical approach to support the use of a short thumb opponens splint to increase hand function with spastic cerebral palsy (Goodman \& Bazyk, 1991). The Rood Cone is a type of splint or positioning device which relies upon several approaches including neurophysiologic and orthokinetic principles

The controversy over treatment approaches and thus splint choice for children with spastic cerebral palsy remains. There also remains a controversy over whether to splint the hand that has 
spasticity. Despite the varying opinions of occupational therapists in regard to splinting for this population, splinting remains a common treatment with perceived, but undocumented effectiveness.

Therefore, research measuring the effectiveness of the Rood Cone was of value. Empirical findings may make a significant contribution to the therapeutic treatment process for the child with spastic cerebral palsy.

\section{Significance of the Study}

The improvement of hand function in children with spastic cerebral palsy is a priority of occupational therapists working with this population (Exner, 1983). While splinting or positioning devices are utilized as an adjunct to treatment with many other patient populations, these adjunctive techniques are not used consistently with children. Splinting, or the application of the Rood Cone, may provide a critical link in optimizing the quality of function for these children.

The controversy over whether to apply a splint or positioning device in cases of spasticity is prevalent among professionals as documented by Neuhaus and colleagues (1981). Even though controversial, several splints and the Rood Cone are applied occasionally in the clinical setting with this population, with perceived value and effectiveness. No documentation was found in 
the literature on the true effectiveness of the Rood Cone on hand function in children with spastic cerebral palsy. 


\section{Chapter 2}

\section{REVIEW OF THE LITERATURE}

Little objective evidence has been offered regarding the effectiveness of hand splints or hand positioning devices for the child with spastic hands (Exner, 1983). There also exists a controversy over whether or not to splint in cases of spasticity (Neuhaus et al., 1981). Theoretically, rationale for splinting has been provided by the neurophysiologic, biomechanical, and Bobath approaches (Blashy \& Fuchs, 1959; Doubilet \& Polkow, 1977; Farber, 1973; MacKinnon et al., 1975; Snook, 1979).

In the earlier years, the theory of "orthokinetics" was coined by Dr. Julius Fuchs, an orthopedic surgeon. Orthokinetics, or the righting of motion, utilizes the exteroceptors of the skin and the proprioceptors of the muscles and tendons to change abnormal muscle tone. Fuchs (1959) constructed a dynamic device in which an "inactive" field is placed over the agonist and an "active" field over the antagonist. Theoretically, this provides a decrease of spasticity in the agonist. Through clinical observation within his practice, Fuchs believed that the "orthokinetic cuff" provided benefits of decreased spasticity, increased coordination, and increased range of motion. Blashy and Fuchs (1959) documented its 
effectiveness in decreasing tone and increasing function in 70 percent of adults who had a cerebral vascular accident. The inelastic segment of the cuff must be placed over the muscles to be inhibited, and the elastic segment over the muscles to be facilitated. This is not a splint in the usual sense, but its purpose is similar to that of other traditional splints.

Bloch and Evans (1977) described an inflatable splint for the spastic hand. In a case study, after two weeks of application of the splint, contractures were reduced with a marked decrease in spasticity. The subject was a nineteen-year-old patient who had sustained a brain injury and showed decorticate spasticity with marked flexion contractures of the upper extremity.

Brennan (1959) conducted a study on 14 people with hemiplegia who wore volar (anterior) splints for an average of three months. All of the patients showed a decrease in hypertonus and most showed an increase in voluntary extension, whereas the unsplinted control showed no improvement. Kaplan (1962) studied ten persons with hemiplegia who were fitted with dorsal (posterior) splints which they wore from 12 to 24 weeks. All subjects showed improvement in decreasing stretch reflexes, and none showed regression. Charait (1968) compared the use of dorsal versus volar resting type splints with twenty hemiplegic patients exhibiting spasticity in the hand. In the ten wearing volar splints, four showed no change in spasticity or voluntary finger or wrist motion, and six exhibited an increase in spasticity. In the ten wearing dorsal splints, 
one showed no change, one showed an increase in spasticity, and eight showed a decrease in spasticity.

Bobath used "key points of control" (1970) to change part of the abnormal reflex pattern throughout the body. In the hand, the fingers can be used as a distal point of control. Doubilet and Polkow (1977) designed a Finger Abduction Splint for the spastic hand in persons post stroke in light of this theory. Since abduction of the metacarpal phalangeal joints inhibits flexion and aids extension, a device to maintain the fingers in abduction is desirable. Preliminary results of clinical observation of the effectiveness of the Finger Abduction Splint have been promising. After one week of implementing this splint to 15 post stroke patients, all patients showed a decrease in spasticity in the hand.

A functional hand splint designed by Joyce MacKinnon (1975) has been applied to children with limited hand function due to flexor spasticity with good results. MacKinnon rationalized that it was necessary to activate the intrinsic muscles of the hand (key to hand function) in order to release the overactive finger flexors and the adductor pollicis. The type of sensory stimulation involved in this process are stretch to intrinsics and pressure and touch to the metacarpal heads. In almost all cases in which the splint has been applied in children (one to five years of age) with spastic hemiplegia or quadriplegia, spasticity has been reduced. This conclusion is only preliminary and observational. 
Snook (1979) found that muscle tone diminished rapidly after splint application and after six hours. Snook applied a Spasticity Reduction Splint which is a variation of the Dorsal Resting Hand Splint. Snook attempted to utilize a reflex inhibiting movement pattern (RIP) in inhibiting abnormal flexor spasticity. This theory is in accordance with the Bobath treatment philosophy. Snook incorporated a RIP into a static splint by extending the thumb and wrist, extending the interphalangeal joints, and abducting the fingers. Through preliminary case study findings, the Spasticity Reduction Splint appears to have an impact on the reduction and normalization of tone in the spastic hand. These changes in tone were subjectively rated according to decreased resistance to passive movement and limb posture in two case studies.

Reflex inhibiting splinting has been used to prevent joint contractures/deformities and to improve muscle tone. Mills (1984) studied eight subjects with diagnoses of traumatic brain injury and implemented reflex inhibiting splinting to various spastic joints. The study showed a significant increase in joint range of motion with elongation of spastic muscles due to splinting, but the muscle group accommodated to the new position as evidenced by no significant change in electromyographic (EMG) activity. No significant reduction in EMG activity was found during the splinted condition compared with the non-splinted condition.

Farber (1982) designed a splint to decrease flexion hypertonicity by several mechanisms. First, the hard cone in the 
palm of the hand was theorized to provide deep pressure onto the insertions of the wrist and hand flexors. This is a direct inhibitory mechanism through the action of the golgi tendon organ (GTO) and acts to reciprocally facilitate the hand and wrist extensors which further enhance extensor activity. There have been no studies found to suggest the effectiveness of this device beyond the theoretical rationale.

Dayhoff (1975) determined the effectiveness of soft versus hard devices to position the "hemiplegic fist." In previous nursing research, the importance of positioning to prevent deformity in the spastic hand has been emphasized. But, soft washcloths, gauze, and sponge rubber have been the devices of choice. Dayhoff suggests a hard device as being more effective in preventing deformity. Through three preliminary case studies involving post stroke adult subjects, Dayhoff implemented a hard hand/positioning device to decrease flexor spasticity and to increase hand function. Positive clinical effects were noted in all three patients even though their fists had been contracted for several years.

Farber and Huss (1974) described a hard cone in the patient's hand to exert pressure on the insertion of the wrist and finger flexors. The small end of the cone is pointed toward the thumb and the flared end toward the little finger side. The theory indicates that the pressure inhibits flexor spasticity. No studies have been found on its effectiveness. 
Goodman and Bazyk (1991) have suggested the effectiveness of a short thumb Opponens Splint on hand function in one child with spastic cerebral palsy. All of the dependent variables of hand function measured displayed a significant improvement except tip and palmar pinch strength. This preliminary case study suggests a need for further studies in this area.

The assumptions about the effectiveness of the Rood Cone mainly stem from the sensorimotor and orthokinetic approaches. Mechanical pressure over tendinous insertions activates deep receptors call pacinian corpuscles (McCormack, 1990). These receptors are found in the deep subcutaneous layers of the skin, especially in the palms of the hands (McCormack, 1990). The inhibitory pressure from the hard plastic cone in the palm is supposed to decrease spasticity in the long finger flexors of the hand. This assumption is derived from the sensorimotor approach to treatment. Margaret Rood, OTR, RPT was a pioneer in the utilization of sensorimotor treatment techniques, hence the name "Rood Cone." On the posterior (dorsal) side of the hand, the elastic wrap is theorized to activate underlying exteroceptors which feed the muscle spindle (by pinching or light touch stimulation) and thus facilitate the underlying extensor muscles. This further decreases spasticity in the hand and comes from the orthokinetic approach to treatment.

While one may conclude that a substantial amount of work has been done with adults, especially the post stroke population, much less has been researched about the effects of positioning devices 
andsplinting with children with spasticity. Also, Trombly and Scott (1989) discussed correct positioning and splinting "although the latter is controversial" in the treatment of the patient with hemiplegia. In Willard and Spackman's book "Occupational Therapy" (1993), equal reference is made to splinting as "a controversial subject among physicians, physical therapists, and occupational therapists" (p. 467). The variety of theoretical rationale for splinting. raises questions about current practice and suggest a needed investigation. 
Chapter 3

\section{DESIGN AND METHODOLOGY}

\section{Research Purpose and Question}

The purpose of this study was to determine the effectiveness of the Rood Cone on hand function in children with spastic cerebral palsy. The question was whether or not there was a change in active range of motion, passive range of motion, pinch strength, spherical grasp strength, and cube stacking ability after the application of the Rood Cone. This study used quasi-experimental methodology in which the subjects were utilized as their own control. The treatment of cerebral palsy is individual, and the client's progress is not measured against an absolute, nor compared with another's performance, thus the subject was used as his/her own control.

\section{Research Objective, Questions, Hypotheses}

The objective of this study was to determine the effectiveness of the Rood Cone on hand function in children with spastic cerebral palsy. The research questions were: 1) Will there be a change in active range of motion (AROM), passive range of motion (PROM), 
lateral tip, palmar pinch strength, and one inch cube stacking after the application of the Rood Cone? 2) If there are changes, do these decrease when the Rood Cone is removed for a month?

Five null hypotheses are suggested with respect to application of the Rood Cone:

1. There will be no significant difference between pretest and posttest measurements of active range of motion of thumb abduction, opposition and extension, digit extension, or wrist extension.

2. There will be no significant difference between pretest and posttest measurements of passive range of motion of thumb abduction, opposition and extension, digit extension, or wrist extension.

3. There will be no significant difference between pretest and posttest scores of spherical grasp as measured with the Martin Vigorimeter.

4. There will be no significant difference between pretest and posttest scores of tip, lateral, and palmar pinch strength as measured by the B \& L Pinch Gauge.

5. There will be no significant difference between pretest and posttest scores on the average number of one inch cubes stacked in three trials.

Five null hypotheses are suggested with respect to the removal of the Rood Cone:

1. There will be no significant difference between posttest and post-posttest measurements of active range of motion of thumb 
abduction, opposition and extension, digit extension, or wrist extension.

2. There will be no significant difference between posttest and post-posttest measurements of passive range of motion of thumb abduction, opposition and extension, digit extension, or wrist extension.

3. There will be no significant difference between posttest and post-posttest scores of spherical grasp as measured with Martin Vigorimeter.

4. There will be no significant difference between posttest and post-posttest scores of tip, lateral, and palmar pinch strength as measured by the B \& L Pinch Gauge.

5. There will be no significant difference between posttest and post-posttest scores on the average number of one inch cubes stacked in three trials.

\section{$\underline{\text { Definitions }}$}

active range of motion: the movement of a joint that the child can accomplish without assistance from the therapist, as measured with a goniometer. The child was shown a particular movement by the therapist and then asked to do the same movement on their own to their fullest ability. This range of motion was recorded.

digit extension: thumb interphalangeal extension and finger 
proximal and distal-interphalangeal extension. The child was asked to perform these motions on their own (actively), and with the therapist's help (passively). The verbal cue was, "open your hand as much as possible."

lateral pinch strength: assumed when the thumb pad is in the direction of the lateral surface of the index finger as measured by the B \& L Pinch Gauge. The child was first shown the motion.

The Pinch Gauge was then placed in position in the child's hand and the child was asked to squeeze the thumb against the side of the index finger to their fullest extent. The numerical reading on the Gauge was recorded.

palmar pinch strength: assumed when the thumb pad is in the direction of the index or middle fingers as measured by the $B$ \& $L$ Pinch Gauge. The child was first shown the motion. The Pinch Gauge was then placed in position in the child's hand and the child was asked to squeeze the thumb against the pad of the index finger to their fullest extent. The numerical reading on the Gauge was recorded.

passive range of motion: the movement of a joint that the child can accomplish given assistance from the therapist, as measured with a goniometer. The child was shown a particular movement and asked to do the same movement on their own to their fullest ability. The therapist then gently assisted the movement to its end range. This end range of motion was recorded.

release from pinch pattern: extension of index proximal- 
interphalangeal and distal-interphalangeal joints and palmar abduction of the thumb as measured by the ability to stack and release one inch cubes. The child was shown how to stack one cube on top of another and then asked to do the same on their own. The number of cubes stacked was recorded.

spherical grasp strength: assumed when the five fingers are flexed around an object and held against the palm as measured by the Martin Vigorimeter. The ball of the Martin Vigorimeter was placed in the palm of the child's hand. The child was then asked to squeeze the ball to their fullest extent. The numerical value on the Vigorimeter is noted.

thumb extension: occurring at the interphalangeal joint, the ability of the thumb to straighten. The child was shown the movement and then asked to do the same movement to their fullest extent. This active range was recorded. The child was then asked to do the same movement, this time with assistance from the therapist to the end range. This passive range was recorded.

thumb palmar abduction: with back of hand on table, thumb points toward ceiling. The child was shown the movement and then asked to do the same movement on their own. This active range of motion was recorded. The child was then asked to do the same movement, this time with assistance from the therapist to the end range. This passive range of motion was recorded.

thumb radial abduction: with back of hand on table, thumb points 
toward wall. The child was shown the movement and then asked to do the same movement on their own. This active range of motion was recorded. The child was then asked to do the same movement, this time with assistance from the therapist to the end range. This passive range of motion was recorded.

thumb opposition: assumed when thumb pad meets pad of little finger. The child was shown the movement and asked to do the same movement on their own. This active range was recorded. The child was asked to do the same movement this time with assistance from the therapist to the end range. This passive range of motion was recorded.

\section{Assumptions}

The most obvious pre-formed ideas about the sample in this study were that the children would be able to follow directions when asked to imitate a prehension pattern, to squeeze a ball with their greatest effort, to open their hand to its fullest, and to stack as many cubes as possible.

The child will be able to communicate in some manner. The child must have spasticity in the flexor musculature of the hand and be between the ages of five and fifteen.

Children with spastic cerebral palsy cannot be compared to each other since each child is very individual with respect to their presenting problems and the treatments they receive. Therefore, it 
was assumed that a control group could not be used. Instead, the subjects were used as their own controls. However, it was assumed that all of the children chosen for the study had varying degrees of spasticity in their hands.

\section{$\underline{\text { Limitations }}$}

Factors other than the implementation of the Rood Cone which may have affected the outcome of this study are as follows: lack of control over parental and child adherence to the protocol of daily wearing time, and unknown simultaneous ongoing therapeutic intervention which may have occurred during the study.

Spontaneous use of the hands, and use of the hands in daily living situations were not assessed.

An upward trend following an initial exposure to the testing measurements may exist due to learning and practice. Also there may have been difficulty for the researcher and data collector to maintain objectivity. To offset this, the researcher did not view the pre-test data until all post-test measurements were taken.

Inference to a larger population of children with spastic cerebral palsy must be limited due to the small sample size, sample homogeneity, and the lack of a control group. 


\section{$\underline{\text { Population }}$}

Nine children, two with bilateral spastic hands, yielding eleven hands were examined. The children were identified by the program analyst for the Special Education sector of Fresno Unified School System as being appropriate for the study. Criteria for being selected included having the diagnosis of Cerebral Palsy, having spasticity in the hand(s), and being between the age of five and fifteen. Subjective criterion included a previous record of parental compliance with home programs.

\section{Methodology}

There was a pre-test administered prior to application of the positioning device. The post-test was administered after one month of wearing the Cone. The Cone was then removed. After one month of no Cone wearing, a post post-test was administered to determine if there were positive changes initially, did they then decrease with the absence of the Cone? This last part strengthened the relationship of change to the Cone. 


\section{$\underline{\text { Procedures }}$}

Prior approval by the Human Subjects Institutional Review Board was obtained for this study in November 1992 (See Appendix A). Following this approval, Fresno Unified School District offered a letter in support of the study at Ginsburg Elementary School, a school for children with special needs (See Appendix B). Finally, a letter of confirmation was obtained from the principal of this school (See Appendix C). Initial selection of the population was determined by the program analyst for the special education sector of the Fresno Unified Schools. The program analyst had criteria for selection of a child into the research study including a diagnosis of Spastic Cerebral Palsy with involvement in the hands, and between the ages of five and fifteen. The program analyst was then given ten copies of the initial letter requesting the participation of a child in the study (See Appendixes D \& E). The letter was sent out by the school to the parents of the selected children. The school determined if there was a need for the correspondence to be in Spanish or English. The return envelope was pre-stamped and had the researcher's home mailing address on it. Thus, initial requests for participation were confidential until the letter is returned and signed. This last aspect of the procedure was requested by the principal and the special education program analyst for the school. 
When parents returned letters with a favorable reply to participate in the study, the children were further screened by the researcher. The children were required to follow directions when asked to imitate a prehension pattern, to squeeze a ball with their greatest effort, to open their hand to its fullest, and to stack as many cubes as possible. The children were required to communicate in some manner. The parents were then sent a brief note (see Appendixes $F \& G$ ), a formative agreement letter to participate in the study (see Appendixes H \& I), and a letter of consent to photograph the hand(s) of their child (see Appendixes $\mathrm{J} \& \mathrm{~K}$ ), again with prestamped return envelopes enclosed. When this final agreement and the consent to photograph were returned, the study began.

Before application of the Rood Cone, a pretest was administered to determine the baseline function of the spastic hand. The measurements included active and passive range of motion (as measured with a goniometer), spherical grasp strength (as measured with the Martin Vigorimeter), and lateral, tip, and palmar pinch strength (as measured with the B \& L Pinch Gauge), and the number of one inch cubes stacked.

The child then was asked to wear the Rood Cone in both hands for three hours in the morning and three hours in the afternoon everyday for one month. Both the child's teacher and their parent(s) were instructed in how to apply the device and the minimal number of wearing hours required. It was emphasized that the Cone was not to interfere with any learning activities, self-care issues nor 
interactive play. Caretakers were told to apply the Cone during "down" times.

During this month, weekly check-up calls were made to the child's home to encourage proper administration of the Rood Cone. A Spanish interpreter was used to assist with phone calls to the Spanish speaking families. At the end of the one month wearing period, a posttest was administered, measuring the previously stated variables.

The Rood Cone was then removed. Finally, a one month followup post-posttest was administered to determine if there were changes associated with the absence of the Rood Cone.

The child was then given his/her Rood Cone and a thank you phone call was made to the parent. The parent was told that the Rood Cone was not being monitored further, and that it was up to them and their therapist if they would like their child to continue wearing the Cone or not.

\section{Measurements}

In the study, four general areas of hand function were tested. These were active and passive joint range of motion, tip, lateral, and palmar pinch strength, spherical grasp strength, and cube stacking. Joint range of motion is measured with a goniometer. Pinch strength was measured with a B \& L Pinch Gauge. Spherical grasp strength 
was measured with the Martin Vigorimeter. Cube stacking ability was tested with one inch wooden cubes.

Joint measurement was defined as: the arc of motion through which a joint passes. Active range of motion was defined as: the arc of motion through which a joint passes when moved by the muscles acting around that joint. Passive range of motion was defined as: the arc of motion through which a joint passes when moved by an outside force, such as the therapist.

The child was asked to imitate various motions at the wrist and finger joints and the therapist measured the child's range of motion with a goniometer. The child first imitated the motions by $\mathrm{him} / \mathrm{h}$ erself so the therapist could measure active range. Then the therapist assisted the child when measuring passive range of motion and measured the full range.

Tip strength was measured when the thumb pad could come in contact with the pad of the index finger. It required very fine coordination. Lateral strength was measured when the thumb pad came in contact with the lateral surface of the index finger. Palmar pinch strength was measured when the thumb pad came in contact with both the middle and index fingers.

With the child sitting, arm in at the side, elbow flexed to approximately ninety degrees, and forearm in neutral, the child was asked to squeeze the B \& L Pinch Gauge (Mathiowetz, 1985) in each of these prehension patterns. Three successive trials were recorded for each pattern. 
Spherical grasp is assumed when the hand holds a small ball such as a racquetball. The five fingers are flexed around the object and hold it against the palm (Pedretti, 1990). The thumb must be abducted and opposed to fully oppose the four fingers.

The Martin Vigorimeter (Robertson \& Deitz, 1988) is used to measure spherical grip strength. The instrument is an air filled rubber bulb attached to a pressure gauge. The dial on the manometer has an arrow that rotates and stops at the highest point of pressure exerted. The child was asked to squeeze the rubber bulb three times with a thirty second rest between each squeeze. The average of these three trials was recorded.

Cube stacking requires active extension of fingers and abduction of the thumb to release the cube from the grasp.

Using one inch cubes, the child was asked to stack as many of the cubes as he/she could. The average number of cubes stacked in three trials was recorded.

\section{Data Analysis}

The paired t-test parametric statistic was used to summarize the data collected. With this statistic, the focus is on the dependent variable (assessment of hand function) and determined a difference in pre and posttests. The paired t-test allows one to compare two sets of data at a time (pre and post test measurements regarding application of the Rood Cone). 
Chapter 4

\section{DATA ANALYSIS AND RESULTS}

The data collected, presented and analyzed in this chapter included active range of motion, passive range of motion and cube stacking measurements. The other measurements of hand function were unable to be tested due to the subjects' high degree of spasticity and involvement. Therefore, hypotheses one, two, and five were examined, as well as both research questions.

Seven children with unilateral spastic hands, and two children with bilateral spastic hands yielding eleven sets of data were included in this study. Data was collected between February 1993 through May 1993. Significance was determined by an $p$ value less than .05 throughout the results.

As stated in hypothesis \#1, "there will be no significant difference between pretest and posttest measurements of active range of motion of thumb abduction, opposition and extension, digit extension, or wrist extension," three active range of motion measures increased significantly after application of the Cone. These measures were active thumb radial abduction, active thumb palmar abduction and active metacarpal-phalangeal extension. 
Active thumb radial and palmar abduction measures both had a mean of 0 degrees initially. After application of the Cone, these measures increased to 9 degrees of active thumb radial abduction and 7 degrees of active thumb palmar abduction. The active range of motion measure of metacarpal-phalangeal extension increased by 29 degrees after the application of the Cone. Initially the mean was 125 degrees of extension. After the application of the Cone, the mean increased to 154 degrees.

Likewise, there was a corresponding decrease in these same measures after the removal of the Cone. With respect to removal of the Cone, hypothesis \#1 states, "there will be no significant difference between posttest and post-posttest measurements of active range of motion of thumb abduction, opposition and extension, digit extension, or wrist extension." There was a loss of 7 degrees in active thumb radial abduction and 7 degrees in active thumb palmar abduction after the removal of the Cone. The mean for active metacarpalphalangeal extension decreased by 28 degrees after the removal of the Cone. The mean for active metacarpal-phalangeal extension decreased from 154 degrees to 126 degrees after the removal of the Cone. 
Table 1

Active Range of Motion

(Matching Hypothesis \#1)

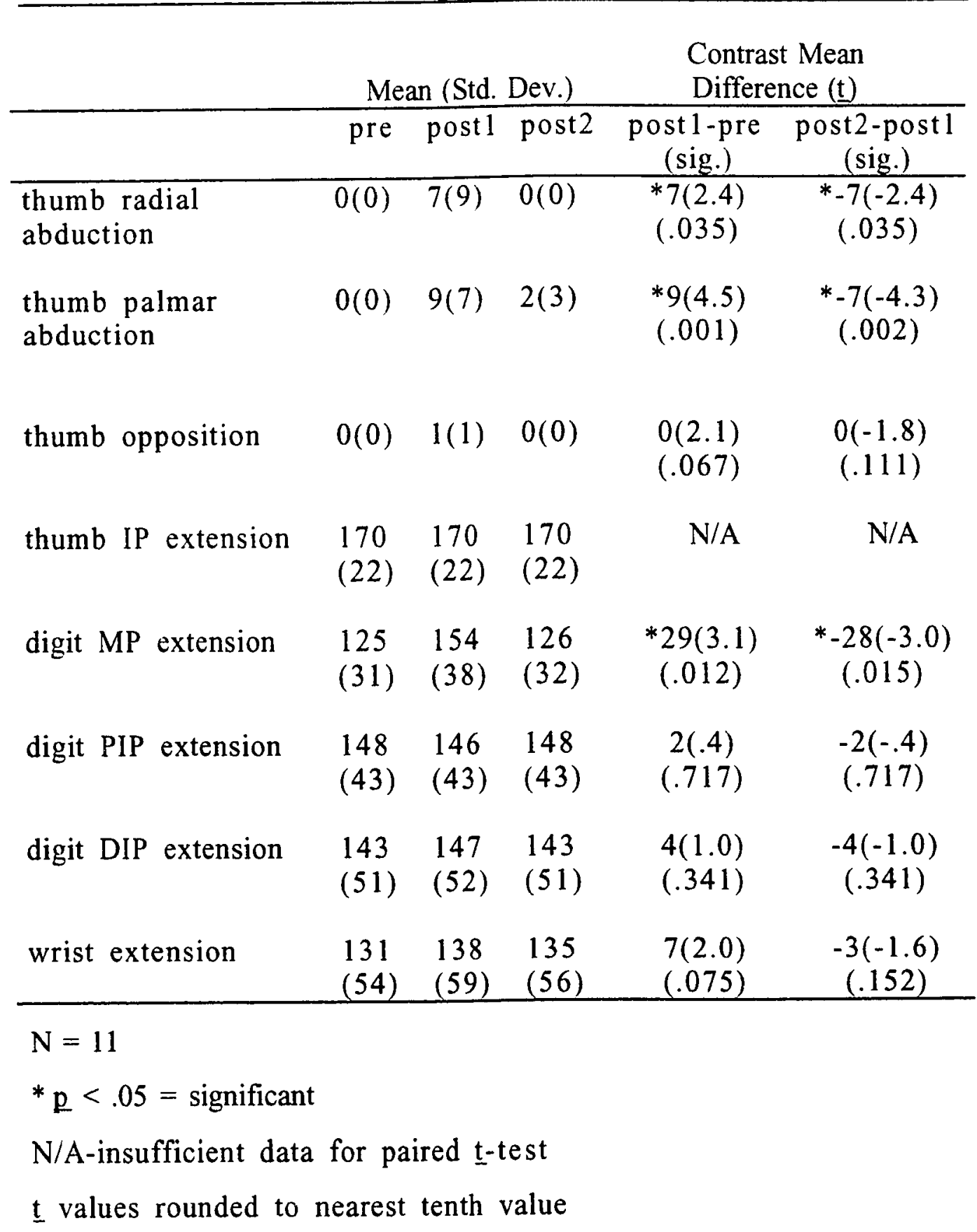


As stated in hypothesis \#2, "there will be no significant difference between pretest and posttest measurements of passive range of motion of thumb abduction, opposition and extension, digit extension, or wrist extension," two passive range of motion measures increased significantly after application of the Cone. These measures were passive thumb radial abduction and passive thumb palmar abduction.

Passive thumb radial abduction initially had a mean of 18 degrees. After application of the Cone, this measure increased to 30 degrees. Passive thumb palmar abduction initially had a mean of 17 degrees, and increased to 33 degrees after application of the Cone. Thus, the mean differences between initial measurement and post application measurements for passive thumb radial abduction and passive thumb palmar abduction were 12 degrees and 16 degrees respectively.

There was a corresponding decrease in these same two measures after the removal of the Cone. With respect to removal of the Cone, hypothesis \#2 states, "there will be no significant difference between posttest and post-posttest measurements of passive range of motion of thumb abduction, opposition and extension, digit extension, or wrist extension." Passive thumb radial abduction decreased from a mean of 30 degrees to a mean of 20 degrees. This yields a mean difference of -10 degrees. Passive thumb palmar abduction decreased from a mean of 33 degrees to a mean of 20 degrees, which yields a mean difference of -13 degrees. 
Table 2

Passive Range of Motion

(Matching Hypothesis \#2)

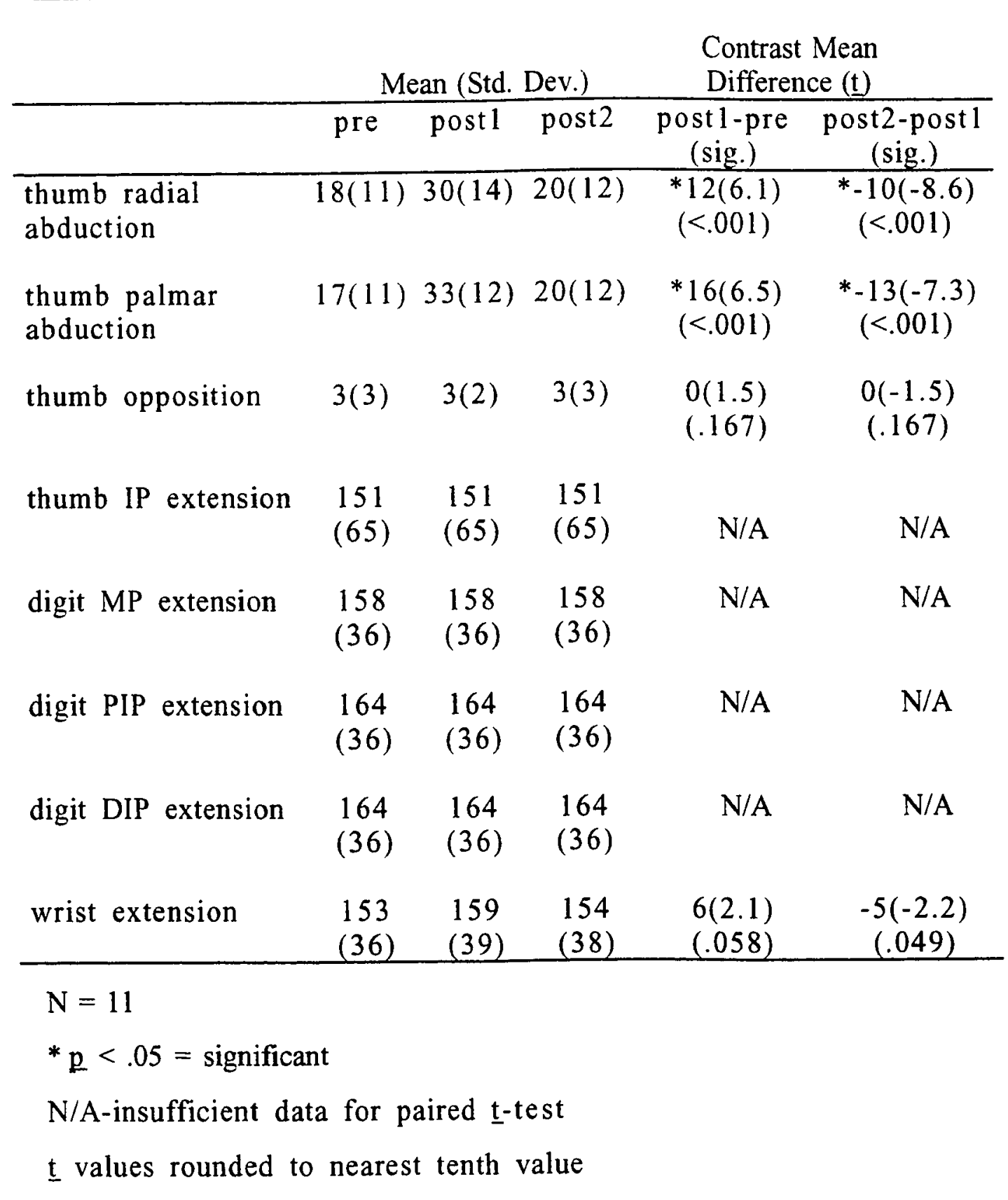


With respect to application of the Rood Cone, hypothesis \#5 states, "there will be no significant difference between pretest and posttest scores on the average number of one inch cubes stacked in three trials." With respect to removal of the Rood Cone, hypothesis \#5 also states that there will be no significant difference in the average number of cubes stacked. These hypotheses cannot be rejected since the results indicate that no significant change occurred after the application or after the removal of the Cone. Initially, none of the subjects were able to stack a cube prior to the application of the Cone. Only three out of the twelve subjects displayed a change in their ability to stack (grasp and release) cubes. One subject increased from zero to two and then returned to zero after the removal of the Cone. The other two subjects increased from zero to one, and then returned back to zero after the removal of the Cone.

With respect to non-significant results, the most important change was the increase of 7 degrees of active wrist extension following the application of the Cone with a probability of .075 . This same measurement decreased 3 degrees following the removal of the Cone.

There remained no change overall in active or passive thumb opposition. Active digit proximal inter-phalangeal (PIP) extension decreased 2 degrees after the application of the Cone, possibly due to the significant increase in digit metacarpal-phalangeal (MP) extension. Active digit distal inter-phalangeal (DIP) extension 
increased 4 degrees after the application of the Cone, and decreased 4 degrees following the removal of the Cone.

In analyzing the results, five measurements of active and passive range of motion were unable to be run statistically. This is due to the fact that the mean difference between pre and post scores was zero. In other words, no change occurred after the application of the Cone or after its removal. These are denoted in the tables as "N/A." These measurements were: active and passive thumb interphalangeal (IP) extension, passive digit metacarpal-phalangeal (MP) extension, passive proximal inter-phalangeal (PIP) extension, and passive distal inter-phalangeal (DIP) extension. 
Chapter 5

\section{SUMMARY, FINDINGS, CONCLUSIONS, AND RECOMMENDATIONS}

The purpose of this study was to determine the effectiveness of a hard cone placed in the palm (Rood Cone) in children with spastic cerebral palsy.

A review of the literature indicated that with one exception (Dayhoff, 1975) no studies were found regarding the effects of a hard cone placed in the palm to reduce spasticity. Furthermore, no studies were offered involving children and the Rood Cone. The exception was a study reflecting the benefits of utilizing a hard surface in the palm to decrease hypertonicity in the hand and wrist versus a soft material, like a washcloth, in adults post stroke.

The present study involved nine children with spastic cerebral palsy, of whom two had hypertonicity in both hands. The measurements of hand function that were able to be analyzed were: active range of motion, passive range of motion, and cube stacking ability. Initially, the researcher had planned to measure spherical grasp strength and pinch strength, both requiring the thumb to be a bit abducted, but the subjects were unable to complete these two measurements due to the significant degree of spasticity in their hands. 
The general research questions which guided the study were: 1) Will there be a change in hand function following the application of the Rood Cone? 2) If so, do the gains decrease with the removal of the Rood Cone for a month?

In this chapter, the methodology, and the findings and conclusions regarding the application of the Rood cone are presented. In the final conclusion, recommendations for further study are made.

\section{Findings and Conclusions}

Using the means, after the application of the Rood Cone, active thumb radial abduction and thumb palmar abduction significantly increased. The null hypothesis stating "there will be no significant difference between pretest and posttest measurements of active thumb abduction (radial and palmar)," may be rejected since there was a significant difference in pre and posttest measurements, $\mathfrak{p}$ value of .035 for radial abduction and .001 for palmar abduction. The results of this entire study were analyzed using alpha level of $\mathbf{p}<.05$. This increase in range of motion from zero degrees to seven and nine degrees respectively could enable a child to grasp and release a washcloth to assist in bathing him/herself as reported by one child's mother. This mother was planning to continue to have her son wear the Cone after the study was over. 
After the application of the Rood Cone, a significant increase of twenty-nine degrees in active digit metacarpal-phalangeal extension occurred. The null hypothesis stating "there will be no significant difference between pretest and posttest measurements of active range of motion of digit extension (metacarpal-phalangeal)" may be rejected since there was a significant difference, $\mathbf{p}$ value of .012 . One mother reported that her daughter now had an increased ability to work her "touch talker," a communication assistive device, since she could now extend her index finger out a bit more.

The two measurements of passive range of motion which increased were determined by one caregiver to allow easier washing of the palm between the thumb and palm with a child who had severe flexor hypertonicity in both hands. The null hypothesis stating "there will be no significant difference between pretest and posttest measurements of passive range of motion of thumb abduction" was rejected since a significant difference was found. Passive thumb radial abduction increased from 18 degrees to 30 degrees with $\mathfrak{p}<.001$. Passive thumb palmar abduction increased from 17 to 34 degrees with $\mathfrak{p}<.001$. It was found that one child had very tight adducted thumbs bilaterally. In this case, the Cone was a bit difficult to place in the proper position at first. When asked if she liked wearing the Cones in her hands, this child answered, "Yes, because they make my hands feel better." This could be because of the deep pressure placed on the insertions of the long finger flexors 
in the palm and the abduction of the thumb, thus relaxing the spastic musculature of the hand (Farber, 1982).

Since the ability of the children to stack one inch cubes remained unchanged overall, one can draw limited conclusions as to the "functional" improvement of the hand demonstrated with the Cone. However, the results obtained for increasing thumb web space and active range of motion are encouraging for the child with significant hypertonicity in the hand. Therefore, the population for whom the Cone had the most success were children having severely adducted thumbs and fisted hands. The results demonstrated were not necessarily an increase in hand function, but a quality of decreased discomfort, increased ease of getting the palm clean and aired out, and increased ability to actively move the thumb and fingers. One mother reported an increased ability for her son to hold and use a washcloth. Also, there may have been functional changes following the application of the Rood Cone, but the measurement of "cube stacking" may not have been sensitive enough to measure the gain.

From the results, it was found that active digit proximal interphalangeal (PIP) extension decreased 2 degrees after the application of the Rood Cone. This change was not significant with a probability of .717. This result may be due to the significant ( 29 degrees) increase in digit metacarpal-phalangeal (MP) extension and the relationship of the long finger flexor tendons crossing both the PIP and MP joints. 
Another non-significant finding of importance was the increase of 7 degrees in active wrist extension following the application of the Rood Cone, $\underline{p}$ value of .075 .

Some individual modifications of the Cone needed to be made throughout the study. With several of the children who sweated profusely on the palms of the hands, a thin moleskin covering was applied around the Cone to prevent the thumb and fingers from sliding or pulling off, and for comfort. A figure-eight strap made of three-quarter inch padded strapping was also utilized for preventing slippage of the Cone. It was emphasized to the parents and teachers that the Cone needed to be kept firmly against the palm of the hand. The strap went from either end of the Cone in a figure-eight pattern around the back of the hand/wrist.

With one child, keeping the thumb fully opposed and on the opposite side of the Cone was difficult. When she completed finemotor tasks with her less involved side, the associated reactions or overflow movements in her involved side were often strong enough to pull her thumb into adduction and extension, causing the thumb to be on the same side of the Cone as the fingers. A small ring-like piece of foam was fabricated to place around the small end of the cone to block the thumb into correct position.

Most of the previous modifications were made in response to teacher, teacher's aides, and parent suggestions/concerns, as they saw the children throughout the day, and had a better overall view of how the Cone was working. 


\section{Discussion and Recommendations}

The Rood Cone should be considered if moderate to severe hypertonicity exists in the flexor musculature of the child's hand(s) as an adjunctive method to direct therapeutic intervention in the treatment of children with spastic cerebral palsy. Since this study involved a small sample size, further investigation involving a larger number of children is called for.

Further research targeting the length of time each day that the Cone is used may be valuable. If the Rood Cone helps reduce spasticity in the hand, how long does a child need to wear the Cone before regression of tonicity is not a concern, if ever? The Cone may provide short term benefits only.

Another question to be raised is how much carry over to functional daily life tasks does the implementation of the Rood Cone offer? The design of this study did not measure changes in functional daily life skills. The measurement of cube stacking ability was the only functional-type indicator, and since it was not a sensitive enough measure, results remained unchanged after the implementation of the Rood Cone. A study involving the ability to use a "touch talker" after the application of the Rood Cone may be of value. Caregivers, teachers, and parents offered valuable information regarding the benefits of the Cone in daily life skills, but these were not measured in this study. Since functional outcomes 
are of significant importance in treatment planning, research investigating changes in functional abilities is called for. 


\section{REFERENCES}




\section{REFERENCES}

Blashy, M. \& Fuchs, R. (1959). Orthokinetics: A new receptor facilitation method. American Journal of Occupational Therapy, 5, 226-234.

Block, R. \& Evans, M.G. (1977). An inflatable splint for the spastic hand. Archives of Physical Medicine and Rehabilitation, 58, $179-180$.

Bobath, B. (1970). Adult hemiplegia: Evaluation and treatment. London: William Heineman Medical Books Ltd.

Brennan, J.B. (1959). Response to stretch of hypertonic muscle groups in hemiplegia. British Medical Journal, 1, 1504-1507.

Charait, S.E. (1968). A comparison of volar and dorsal splinting of the hemiplegic hand. American Journal of Occupational Therapy, 4, 319-321.

Dayhoff, N. (1975). Re-thinking stroke: Soft or hard devices to position hands? American Journal of Nursing, 75, 1142.

Exner, C.E. \& Bonder, B.R. (1983). Comparative effects of three hand hemiplegic children: A pilot study. The Occupational Therapy Journal of Research, 3(2), 75-92.

Farber, S.D. \& Huss, A.J. (1974). Sensorimotor evaluation and treatment procedures for allied health personnel. Indiana University Foundation. 
Goodman, G. \& Bazyk, S. (1991). The effects of a short thumb opponens splint on hand function in cerebral palsy: A singlesubject study. American Journal of Occupational Therapy. 45 , $726-731$.

Kaplan, N. (1962). Effect of splinting on reflex inhibition and sensorimotor stimulation in treatment of spasticity. Archives of Physical Medicine and Rehabilitation, November, 565-569.

MacKinnon, J., Sanderson, E., \& Buchanan, J. (1975). The MacKinnon Splint-A functional hand splint. Canadian Journal of Occupational Therapy, 42, 157-158.

Langlois, S., Mackinnon, J., \& Pederson L. (1991). The effects of splinting on the spastic hemiplegic hand: Report of a feasibility study. Canadian Journal of Occupational Therapy, 58(1), 17-25.

Mathiowetz, V., Kashman, N., Volland, G., Weber, K., Dowe, M., \& Rogers, S. (1985). Grip and pinch strength: Normative data for adults. Archives of Physical Medicine and Rehabilitation, $\underline{66}$, 69-74.

Mills, V.M. (1984). Electromyographic results of inhibitory splinting. Physical Therapy, 64, 190-193.

Neuhaus, B.E., Ascher, E.R., Coullon, B.A., Donohue, M.V., Einbond, A., Glover, J.M., Goldberg, S.R., \& Takai, V.L. (1981). A survey of rationales for and against hand splinting in hemiplegia. American Journal of Occupational Therapy, 35, 83-90. 
Pedretti. L.W. \& Zoltan, B. (1990). Occupational therapy: Practice skills for physical dysfunction (3rd ed.). St Louis: C.V. Mosby Co.

Reid, D.T. (1992). A survey of Canadian occupational therapists' use of hand splints for children with neuromuscular dysfunction. Canadian Journal of Occupational Therapy, 59(1), 16-27.

Robertson, A. \& Deitz, J. (1988). A description of grip strength in preschool children. American Journal of Occupational Therapy, 42, 647-652.

Sammons, F. (1991). Enrichments Catalog. Burr Ridge, Illinois: Fred Sammons, Inc.

Schneck, C.M. \& Tona, J.L. (1993). The efficacy of upper extremity inhibitive casting: A single-subject pilot study. American Journal of Occupational Therapy, 47(10), 901-910.

Snook, J.H. (1979). Spasticity reduction splint. American Journal of Occupational Therapy, $\underline{33}$, 648-651.

Spencer, E.A. (1993). Functional restoration: Neurologic, orthopedic, and arthritic conditions. In H.L. Hopkins \& H.D. Smith (Eds.), Willard and Spackman's occupational therapy (8th ed., pp. 467551). Philadelphia: Lippincott.

Trombly, C.A. \& Scott, A.D. (1989). Occupational therapy for physical dysfunction. Baltimore: Williams and Wilkins Co.

Umphred, D.A. \& McCormack, G.L. (1990). Classification of common facilitory and inhibitory treatment techniques. In D.A. 
Umphred (Ed.), Neurological Rehabilitation (2nd ed., pp. 111161). St. Louis: C.V. Mosby. 
APPENDIXES 
APPENDIX A

HUMAN SUBJECTS APPROVAL 
Orice of the Academic Vice Presldent. Callormia $95192-0025$ - 108/924-248C

To: Emily Devere

$7930 \mathrm{~N}$. Sunnyside

Clovis, CA 93611

From:

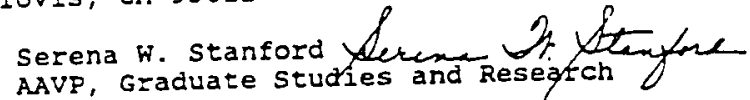

Date: November 5, 1992

The Human Subjects-Institutional Review Board has approved your request to use human subjects in the study entitled:

"The Effects of the Rood Cone on Hand Function in children with Spastic cerebral Palsy"

This approval is contingent upon the subjects participating in your research project being appropriately protected from risk. your research project being appropriately pity of the subjects' This includes the protection of the anonymicy of identity when they participate in your research project, and with regard to any and all data that may be collected Irom the subjects. The Board's approval includes continued monitoring of your research by the Board to assure that the subjects are being adequately and properly protected from such risks. If at any time a subject becomes injured or complains of injury, you must notify $\mathrm{Dr}$. Serena stanford immediately. Injury includes but is not limited to bodily harm, psychological trauma and release of potentialjy damaging personal information.

Please also be advised that each subject needs to be fully informed and aware that their participation in your research project is voluntary, and that he or she may withdraw from the project is voluntary, and that he or she marther, a subject's participation, project at any time. services the subject is receiving or will receive at the institution in which the research is being conducted.

If you have questions, please contact me at 408-924-2480.

cc: Gordon Burton 
APPENDIX B

LETTER OF CONFIRMATION-FRESNO UNIFIED SCHOOL DISTRICT 


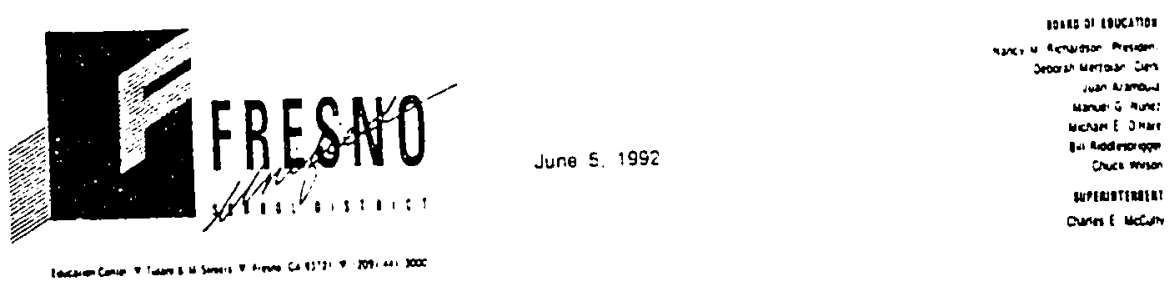

Emily $M$ Bair

1317 Eas: Sample

Fiesno. CA 93710

Dear Ms. Bair.

have revewed your thesis prodosal regarding "The EHects of the Rood Cone on Hand Function I have reviewed your thesis prososal rogardistant tha! you wish to measure suen elements as in Cnilderen with Spastie Cereoral Palsy. active and passive range of motion. Spherical grasp stengin. You intend to do this witt. about 15

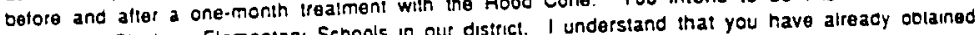
children at Ginsourg Elementary Sehools in out disinel.

preliminary approval trom Mr. Harold Housenoldep and Ms. Joyce Fisher lor this siudy.

proposal you are authorzed to begin the process of tinding subjects at This aythorization is strictly subject to your compirance with the lallowing conditions

That you obtain the voluniary cooperation o! the principal at Ginsburg. I That you obtain ine voluniary cooperallon ot hour proposal to him. There recommend thal you contaci hum and explain yo

- That you oblan the voluntay cooperation of any teachers to be That you oblan the voluniational frogram and there is no involved. They have a lull instrueton
requitement that they participate.

- That any children involved are volunteers. You must obtain written ant authorization trom the parent of any school's permanent file for the child authorization should be placed in the schools permanani will sulfice. The agreement form you submitted with your proposal will

- That you limit your data gatnering to that coenufied in your proposal, and

- That upon completion of your study. you submit a copy ol you lindings to the principal.

Best of wishes for the suecesstul completion of this project.

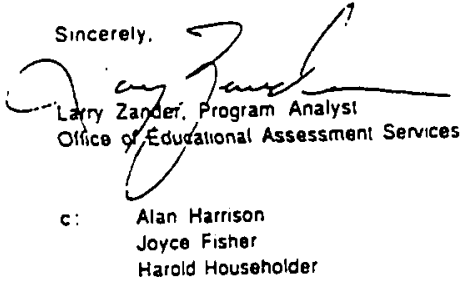

An Equal Opportunity/A/firmoine Action Employer 
APPENDIX C

LETTER OF CONFIRMATION-PRINCIPAL OF SCHOOL 


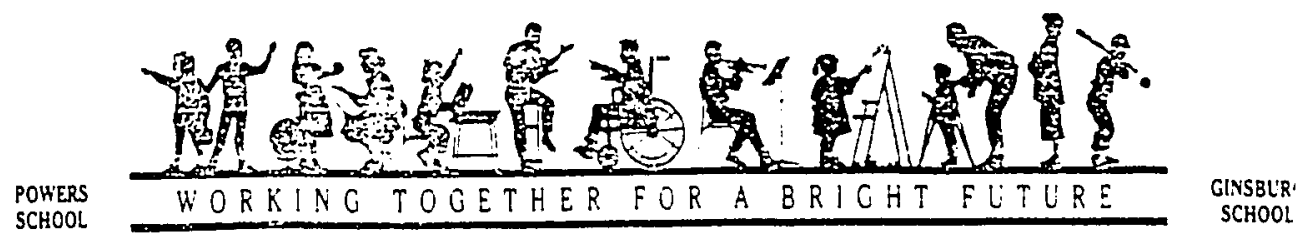

October 20, 1992

Dear Emily,

This is a letter to confirm my support for completing your research study at Ginsburg School. I understand that this study is titied The Effects of the Rood Cone on Hand Function in Children with Spastic Cerebral Palsy and involves students with some degree of spasticity in their hand(s).

Sincerely,

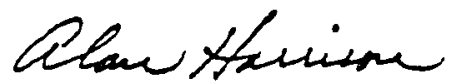

Alan Harrison, Principal

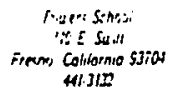

frewo Larwe s.ow oune

Ginsourg Senso 6. $E$ dethon 
APPENDIX D \& E

REQUEST FOR PARTICIPATION-ENGLISH \& SPANISH VERSIONS 


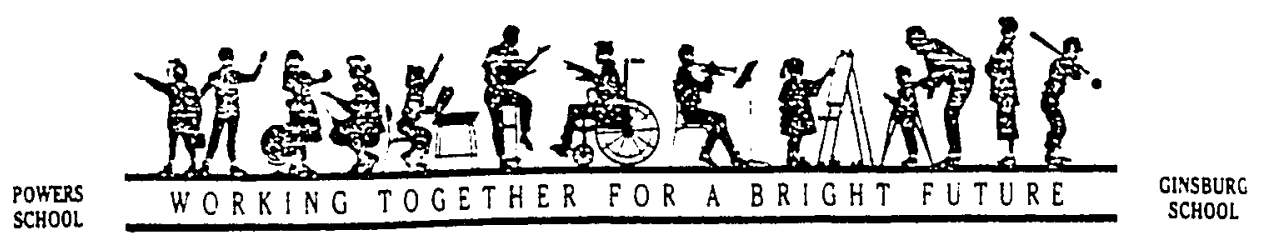

To the parents of

Jasuary 1,1993

My name is Enily Devere, and I am a graduate studeat involved in a research study at Ginsburg. I bave ideotified your child as possibly benefiting from this study. The study deals with children with some degree of tone or spasticity in one or both band(s).

The purpose of the study is to determine the effectiveness of a positioning hand device on band function. The potential benefit is that the child may show improved band function and decreased tone in the band. There are no risiks involved.

This study is supported by Fresno Unified School District, the prineipal at Ginsburg Elementary (Alan Harrison), and San Jose State University.

If you are willing to have your child participate in the study, please sign the bottom of this letter and return it to me in the envelope provided by January 15, 1993. I can be reacbed at (209) 2999715 if you bave any questions.

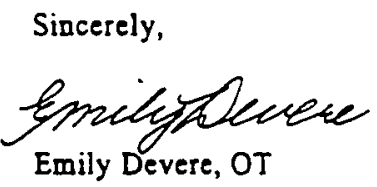

sigoature:

curredt address:

phone: 


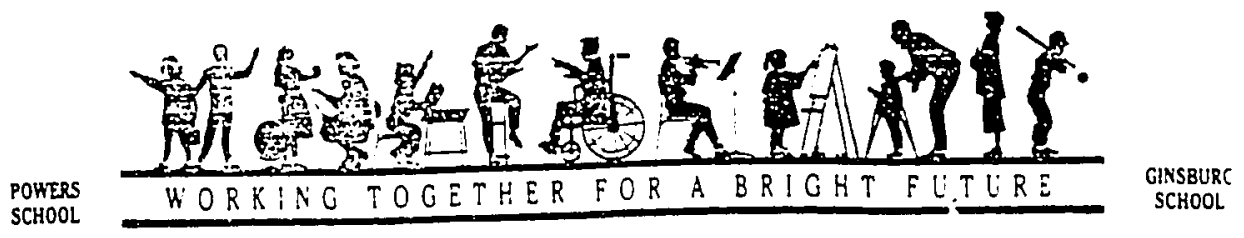

A los padres de:

January 1, 1993

Mi nombre es Emilia Devere, estudiante calificada envuelta en un estudio especial en la escuela Ginsburg He' identificado a su hijo (bija) que es posible beneficie en este estudio. El estudio trata co el grado de tono $0^{\prime}$ movimiento muscular en una $o^{\prime}$ las dos manos.

El estudio es para determinar el beneficio que un aparato tenga en la funcion de la mano. El beneficio posible es que su hijo (hija) pueda mejorar el movimiento en su mano y reducir el tono en la mano. Este estudio no tiene riesgos.

E) Fresno Unified School District soporta este estudio, tambiea el principal (Alan Harrison) en la escuela Ginsburg, y San Jose' Universidad.

Si desean que su hijp (bija) participe en el estudio, favor de firmar y completar el informe al final de esta carta y devuelva en el sobre antes de January ls, 1993.

Sinceramente,

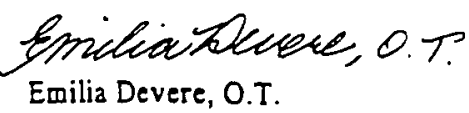

firma:

direccion:

telephono: 
APPENDIXES F \& G BRIEF NOTE TO PARENTS-ENGLISH \& SPANISH VERSIONS 
To the parent(s) of

Please sign and date the tw'o copies of the agreement, keeping one for your reference and sending the other one back to me in the envelope provided. I will be in touch with you by phone or in person after I have collected the initial measurements of hand function from your child. I look forward to working with your child and having him/her in my study. Thank you for allowing me to work with them.

Sincerely,

Emily M. Devere 


\section{SIEN|

School of Apolled Amp and Selences - Degortment of Occupallonel Therapy

One wasningion Square. San jose Cattornia 95192-0059. Main OHice 408:924-3070. Fielewopk Ollice 408/924-3078

10 Marzo 1993

Para los padres de

Por favor firme y ponga la fecha en las dos pajinas de las dos

formas. Una forma para usted, y otra forma para mi en el correo por favor. Muchas gracias por dandome permiso para trabajar con su nino(a).

Sinceramente,

Emilia Devere 
APPENDIXES H \& I

FORMATIVE AGREEMENT-ENGLISH \& SPANISH VERSIONS 


\section{SJISl Sintusese}

Othee of the Acendemic Vice Prealoent - Assoclate Acodemic Vice Prosidont - Gradualo Sludies and Resesteh One Washingion Sousre - San Jose, Cailiornia 95:92-0025 - 409:924-24\$0

\section{AGREEMENT TO PARTICIPATE N RESEARCH SAN JOSE STATE UNTVERSITY}

RESPONSIBLE NVESTIGATOR: Emily Devere

TITLE OF PROTOCOL: the Effects of the Rood Cone on Hand Function

Your child is invited to participate in a research study that is investigating the effects of a hand positioning device. the results of this study should further our understanding of the usefulness of this device.

I understand that

1) I will be asked to apply the splints for three bours in the morning and three hours in the afternoon to my child's hands. This must occur everyday for one month.

2) There are no risks involved.

3) The possible benefits of this study to my child are that he/she may develop better use of his/her hands and/or show a decrease in spasticity in the hand(s).

4) Alternate procedures include an opponens splint, a finger abduction splint or a spasticity reduction splint.

5) The results of this study may be published, but any information from this study which can be identified with my child will remain confidential and will be disclosed only with my permission.

6) Any questions about my child's participation in this study will be answered by Emily Devere (209) 299-9715.

Complaints about the procedures may be presented to Lela Llorens, Ph.D., O.T.R. (408) 924-3070, Department Chairperson for Occupational Therapy. For questions or complaints about research subject's rights, or in the event of a research-related injury, contact Serena Stanford, Ph.D., Associate Academic Vice President for Graduate Studies and Research at (408) 924-2480. 
7) My consent is given voluritarily without being coerced; my child may refuse to participate in this study or in any part of the study, and I may withdraw my consent at any time, without prejudice to my relations or my child's with San Jose State University.

8) I have received a copy of this consent form for my file.

HAVING READ THE INFORMATION ABOVE, I HAVE MADE A DECISION WHETHER OR NOT MI CHILD MAY' PARTICIPATE. MY SIGNATURE INDICATES THAT MY CHILD MAY PARTICIPATE AND IS WILLING TO.

date parent or guardian signature relation to child

investigator's signature print child's name 


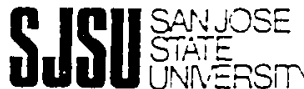

Otlice of the Acacemic Vlee President - Associate Acacemic Vico President - Gradualo Studies ane fiasearth

One Washingion Square - San Jose, Calitornia 95192-0025 - 406.9i-2480

CONTENIO PARA PARTICIPAR EN RTESTIGACIÓN U.TVERSIDAD DE EL ESTADO DE S.AN JOSÉ

NVESTIGADOR RESPONSABLE: Emilia Devere

TITULO DE PROTOCOLO: Los Efectos del 'Rood Cone' en el

Funcionamiento de la Mano

Su nino(a) esta invitado(a) a participar en un estudio que esta investigando los efectos de un mecanismo de posición para la mano. Los resultados de este estudio aumentara nuestro entendimiento en cuanto a la utilidad de este mecanismo.

\section{Entiendo que}

1) Se me pedira que coloque las tablillas en la(s) mano(s) de mi niño(a) durante (3) tres horas en la mañana y tres horas en la tarde. Esto debe ocurrir diariamente durante un mes.

2)No hay ningun peligro.

3)Los posibles beneficios de este estudio para mi niño(a) es que pueda desarrollar mejor uso de su(s) mano(s) y/o mostrar disminución en la hipertonicidad muscular en la(s) mano(s).

4)Procedimientos alternantes incluyen tablillas oponentes, tablillas de abducción de un dedo o una tablilla para reduccion espastica.

5)Los resultados de este estudio pueden ser publicados, pero qualquier informacion de este estudio que pueda ser identificado con su niño(a) permanecera confidencial y podra ser revelado solo con mi permiso.

6)Cualquier prequnta sobre la participación de mi niño(a) en este estudio sera countertado por Emilia Devere (209) 299 9715. Quejas sobre los procedimientos pueden ser expuestos a Lela Llorens, Ph.D., O.T.R. (408) 924-3070, Presidente del Departamento para Terapia Ocupacional. Para preguntas 0 quejas sobre los derechos de investigación de el sujeto, o en la eventualidad de una lesión relacionada con la investigación pongase en contacto con Serena Stanford, Ph.D., Vice Presidente Academico Asociado para Estudios Superiores e Investigación a el (408) 924-2480. 
7) Mi consentimiento es otorgado voluntariamente $y$ sin coerción: mi nino(a) puede rehusar participación en este estudio, y vo puedo revocar mi consentimiento en cualquier momento, sin prejuicio para mi relación, o la de mi niño(a) con la Universidad de el Estado de San Jose.

8) He recibido una copia de este consentimiento para mi archivo.

HABIENDO LEDDO LA INFORMACIÓN AN,TERIOR, HE TOMADO LA DECISIÓN SOBRE LA PARTICIPACIÓN DE MI NINOO(A). MI FIRMA INDICA QUE MI NINNO(A) PUEDE PARTICIPAR Y ESTA DISPUESTO(A). $\begin{array}{lll}\overline{\text { fecha }} & \overline{\text { firma de los padres o guardian }} & \begin{array}{c}\text { nombre de el niño(a) } \\ \text { relación con el niño(a) }\end{array}\end{array}$

firma de el investigador 
APPENDLXES J \& K

CONSENT TO PHOTOGRAPH-ENGLISH \& SPANISH VERSIONS 


\section{SISISSANOSE}

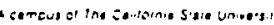

Senool or Applled Arts and Sclencer

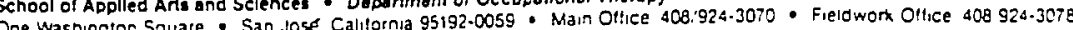

\section{PHOTOGRAPH CONSENT}

1 , the parent of allow Emily Devere to take a photograph of my child's hand(s). I understand that the photograph may be used within the context of her study or for educational purposes.

Signed, 


\section{SISII SAMNMOSE}

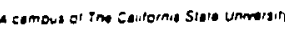

School of Apolied Arts and Selences - Dapartment of Occupattonal Therapy

- San Jose. Calitomia 95192-0059 - Main OHice 409/924-3070 - Fielowonx Olfice 406/924-3078

\section{CONSENTO PARA PHOTOGRAPHIA}

Yo, el padre de doy permiso a Emilia Devere tomar una photographia de los manos de mi hijo(a). Entiendo que la photographia peude ser usada en el contexto del estudio o para educacion.

firma, 